\title{
A comparative look at the exchanges between China and Japan's inorganic compound names, 1842-1945
}

\author{
Hao Chang ${ }^{1}$ (1) \\ Received: 25 July 2019 / Accepted: 7 October 2019 / Published online: 15 November 2019 \\ (c) Springer Nature Switzerland AG 2019
}

\begin{abstract}
Starting from China's loss of the First Sino-Japanese War of 1894, Chinese people began to widely adopt Japanese chemical terms. Inorganic compounds were the most affected field. Before this dramatic change, Chinese inorganic compounds were mostly written word-by-word after their chemical formula. For example, sodium chloride was written as na lï (鈉氯) and potassium chloride as jia lï (鉀氯). However, from the early 20th century, many Chinese books translated from Japanese sources began to switch the order of the elements and inserted the word hua (化) between the two elements. Therefore, the above-mentioned names became lï hua na (氯化鈉) and lï hua jia (氯化鉀). In the end, China's official inorganic naming scheme was created after its Japanese counterpart.
\end{abstract}

Keywords Inorganic chemistry $\cdot$ Chemical nomenclature $\cdot$ Chemical vocabulary $\cdot$ Chemical term

\section{Introduction}

There has been a long history of mutual exchanges between the Chinese and Japanese languages. However, before the First Sino-Japanese War, nearly none of the Japanese science books had been translated into Chinese, while many Chinese books were translated into Japanese, such as Bowu Xinbian (博物新編, New Treatise on Natural Philosophy and Natural History), Gewu Rumen (格物入門, Introduction to Natural Philosophy), Huaxue Chujie (化學初階, Elementary Chemistry), Huaxue Jianyuan (化學鑑原, Elemental Chemistry) and Jinshi Shibie (金石識別, Discrimination of Mineralogy), without making too much impact. The war of 1894 changed everything, and many Japanese books were translated into Chinese, such as Ikeda Kikunae's (池田菊苗) Kinsei Kagaku Kyokasho (近世化學教科書, A Textbook of Modern Chemistry), Fujimoto's (藤本理) Mukikagaku Kyogi (無機化學講義 Lectures on Inorganic Chemistry), Osaka Yukichi's (大幸勇吉) Kaitei Kinsei Kagaku Kyokasho (改 訂近世化學教科書, A Revised Textbook of Modern Chemistry), Kametaka Tokuhei's (鹤高德平) Futsuu Shintai Kagaku Kyokasho (普通新體化學教科書, A New General
Chemistry Textbook) and Yoshida Hikorokurou's (吉田彥 六) Chuutou Saishin Kagaku Kyokasho (中等最新化學教科 書, The Newest Middle School Chemistry Textbook). These books greatly influenced China's chemistry. Many Japanese chemical kanji terms were adopted by the Chinese, such as genso/yuansu (元素, element), genshilyuanzi (原子, atom), muki/wuji (無機, inorganic) and youki/youji (有機, organic).

In the nineteenth century, Western missionaries assisted Chinese scholars in translating Western scientific books. However, these missionaries were too busy spreading the gospel, and had limited ability in Chinese [1]. Also, their limited knowledge of chemistry caused errors and deviations in translation [2]. In our previous article, we reviewed the origins of Chinese and Japanese element names in detail [3]. We found that Chinese element names were hardly influenced by Japan's kanji counterparts. However, Chinese inorganic names, especially those of binary compounds, were highly influenced by Japanese names.

Here, we investigate the exchanges between China and Japan's inorganic names, and further examine the reason why Chinese element names were hardly influenced while the inorganic names were heavily influenced.

Hao Chang

changhao@isu.edu.tw

1 Center for General Education, I-Shou University, Kaohsiung City, Taiwan, Republic of China 


\section{Chinese inorganic names}

Before the chemical nomenclature reform movement led by Antoine Lavoisier (1743-1794) (see Fig. 1), inorganic names originated from their traditional or alchemy names. This kind of name had nothing to do with a substance's composition. After the reform, antique names such as fixed vegetable alkali, green copperas and vitriol of silver became carbonate of potash, sulfate of iron, and sulfate of silver. Additionally, Lavoisier's chemical names were a part of the chemistry. Take acid in his theory as an example: an acid formed by the oxidization of a nonmetal element. The number of oxygen atoms determines the strength of the acid, and Lavoisier used a suffix to illustrate this chemical change. English and German also adopted this idea. For example, in English an acid with the -ous suffix is weaker than one with an -ic suffix, e.g. sulfic acid and sulfrous acid; nitric acid and nitrous acid. The suffix -ate was used to name salts from -ic acids, while the suffix -ite was used to name salts from -ous acids, such as sulfate of zinc and sulfite of zinc [4].

Let's talk first about Chinese names for binary inorganic compounds before visiting inorganic acids. Several binary compounds appeared in A Medical Vocabulary in English and Chinese (《醫學英華字釋》, Yixue Inghua Zishi) by Benjamin Hobson (合信, Xin He, 1816-1873) (see Fig. 2). He simply used the traditional Chinese names in his book, for example, red oxide of iron was tiehong $\operatorname{san}$ (鐵紅散, iron red power), grey oxide of mercury was shuiyin san (水銀散, quicksilver powder) and red oxide of mercury was sanxian dan (三仙丹, three fairies elixir) [5]. In Gewu Rumen (格物入門, Introduction to Natural Philosophy, 1868), William A. P. Martin (丁韙良, Weiliang Ding, 1827-1916) (see Fig. 3) formed binary compound

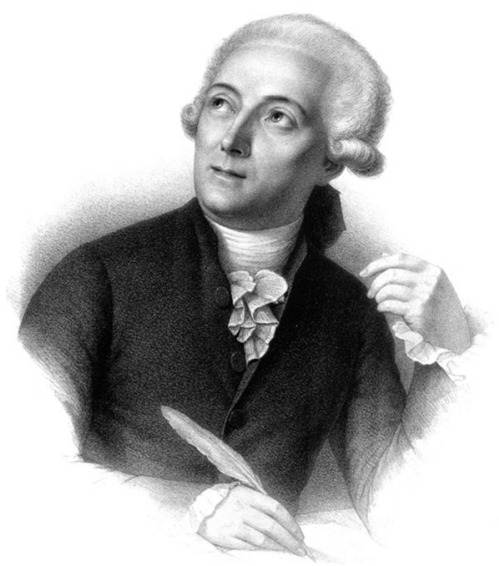

Fig. 1 Antoine Lavoisier

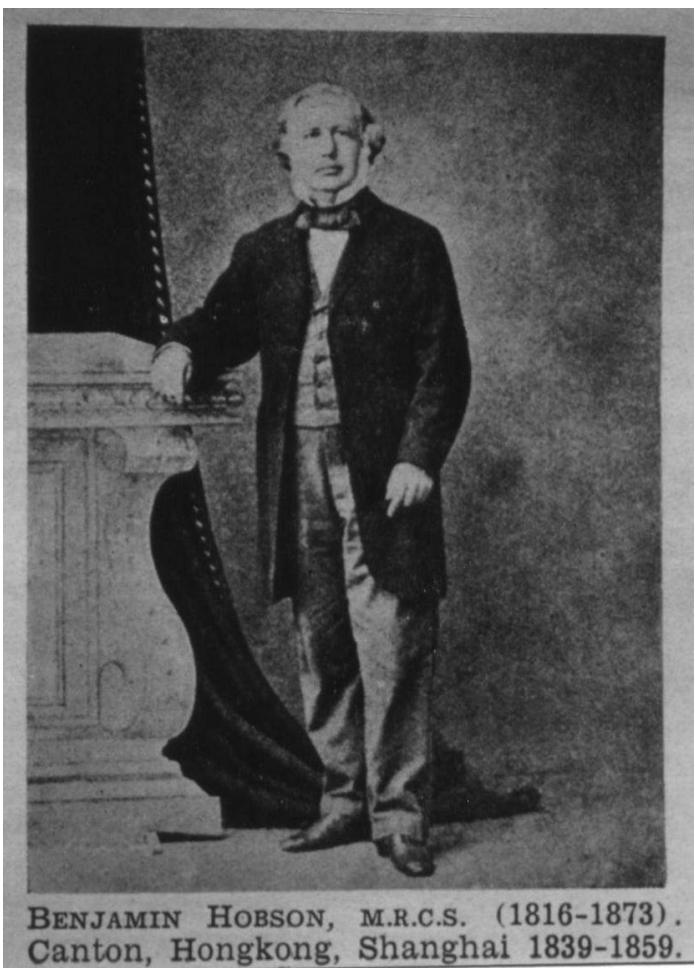

Fig. 2 Benjamin Hobson

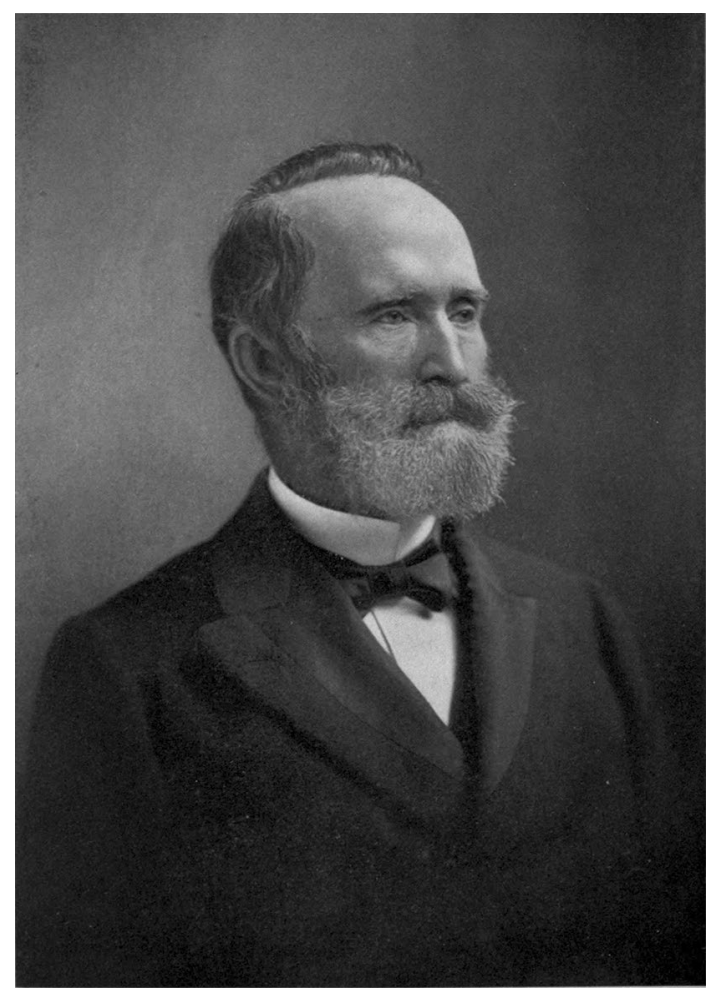

Fig. 3 William A. P. Martin 
names using the elements. For instance, he called oxide of iron and oxide of lead, oxygen iron (養鐵, yang tie) and oxygen lead (養鉛, yang qian) [6].

This methodology was very uncommon in 19th century China. Perhaps it was an exception because in these names the order of the elements was reversed compared with the chemical formula. The names coined by John Glasgow Kerr (嘉約翰, Yuehan Jia, 1824-1901) (see Fig. 4), John Fryer (傅蘭雅, Lanya Fu, 1839-1928) (see Fig. 5), Shou Xu (徐壽, 1818-1884) (see Fig. 6) and Anatole Billequin (畢 利幹, Ligan Bi, 1837-1894) were created after these elements' formula orders. These names included sodium 2 oxygen (鐻一養, sodium oxide, $\mathrm{Na}_{2} \mathrm{O}$ ) and sodium 2 oxygen 2 (鐻_養二, sodium peroxide, $\mathrm{Na}_{2} \mathrm{O}_{2}$ ) of Huaxue Chujie (化學 初階, Basic Chemistry, 1870); iron oxygen (鐵養, protoxyd of iron, $\mathrm{FeO}$ ), iron2 oxygen3 (鐵_養三, peroxyd of iron, $\mathrm{Fe}_{2} \mathrm{O}_{3}$ ) [7] and iron oxygen3 (鐵養三, ferric acid, $\mathrm{FeO}_{3}$ ) of Huaxue Jianyuan (化學鑒原, Elementary Chemistry, 1871); lithium sulfur (鉐璜, lithium sulfide, LiS) [8] and lithium chlorine (鉐綠, lithium chloride, $\mathrm{LiCl}$ ) of Huaxue Zhinan (化學指南, A Guide to Chemistry) [9]. They followed nearly the same rules. Only Billequin used right superscript numbers instead of right subscript numbers.

As late as the early 20th century, Chinese inorganic compound names began to have a connective word hua (化, change) placed between the two elements. "A compound of oxygen can have the word ' $h u a$ ' to indicate the element

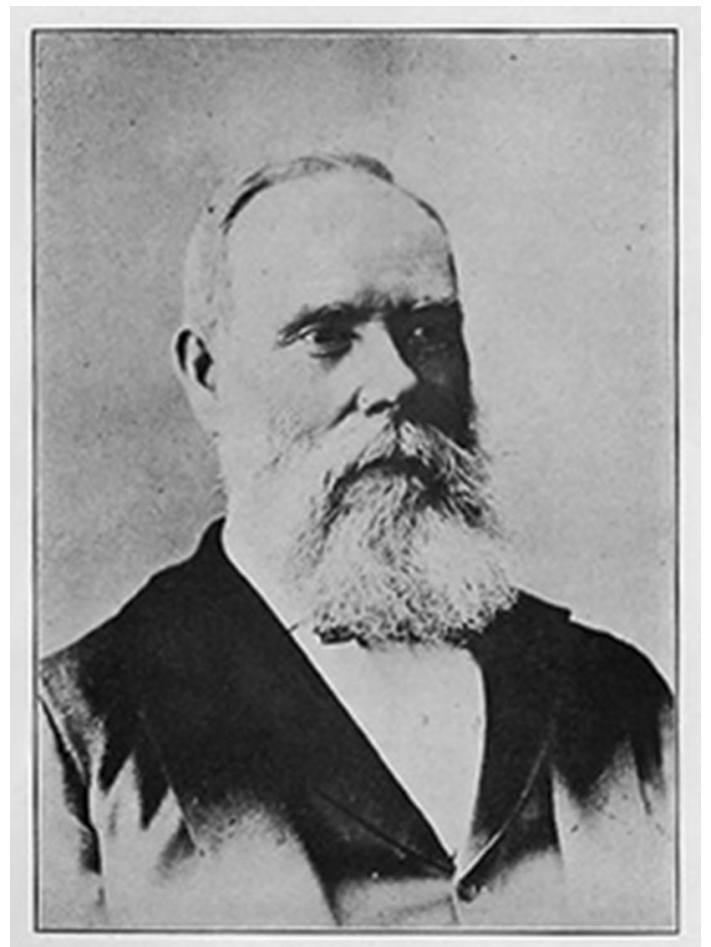

Fig. 4 John Glasgow Kerr

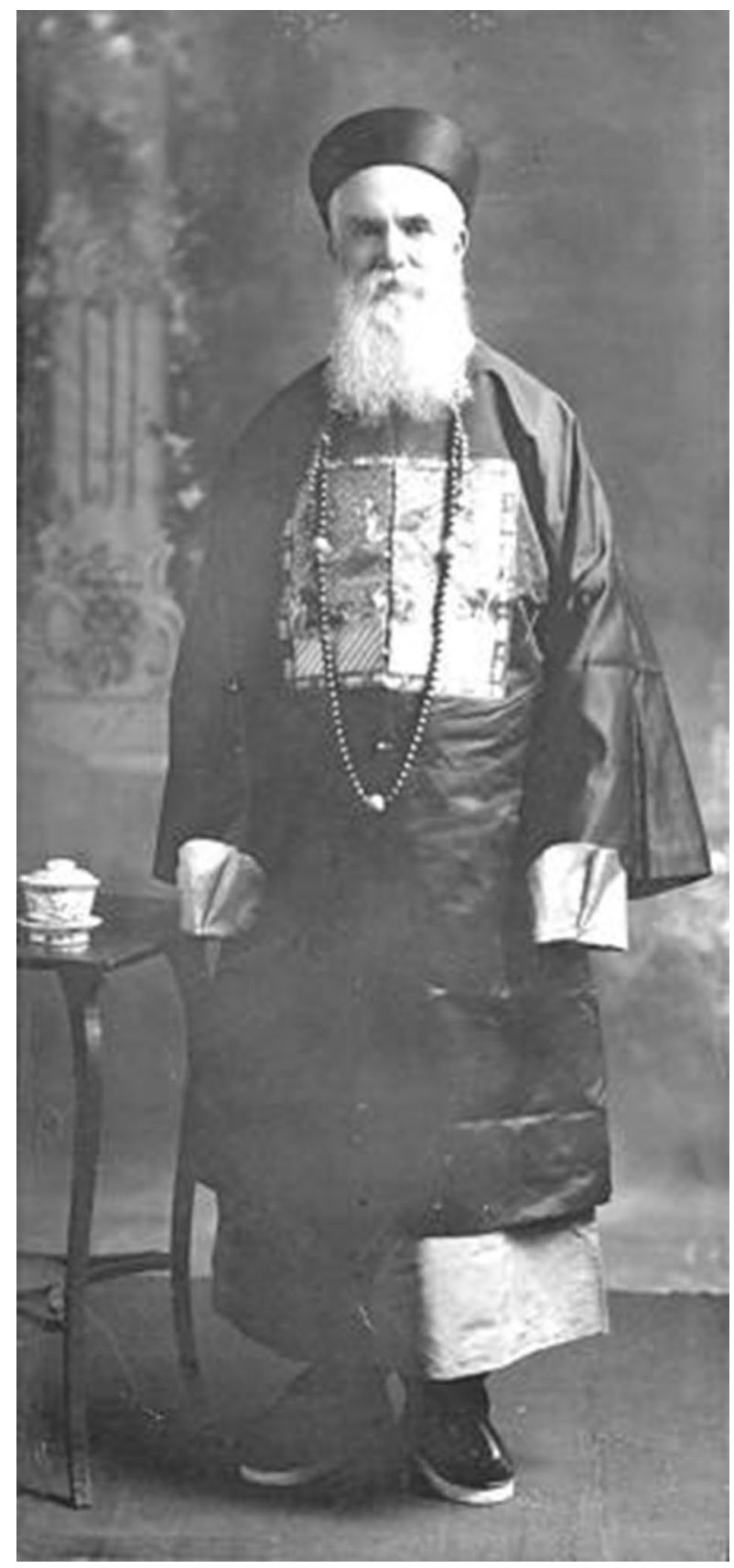

Fig. 5 John Fryer

has been oxidized", Heqin Yu (虞和欽, 1879-1944) (see Fig. 7), who once studied chemistry in Japan, explained [10]. Compounds of chlorine and bromine also use the same word to form chloride and bromide, such as oxygen hua copper (氧化銅, copper oxide), chlorine hua silver (氯化 銀, silver chloride) and bromine hua silver (溴化銀, silver bromide) [11]. In order to show Chinese readers the differences between Chinese names and Japanese names, Yu had compiled a list of Chinese and Japanese inorganic terms. 


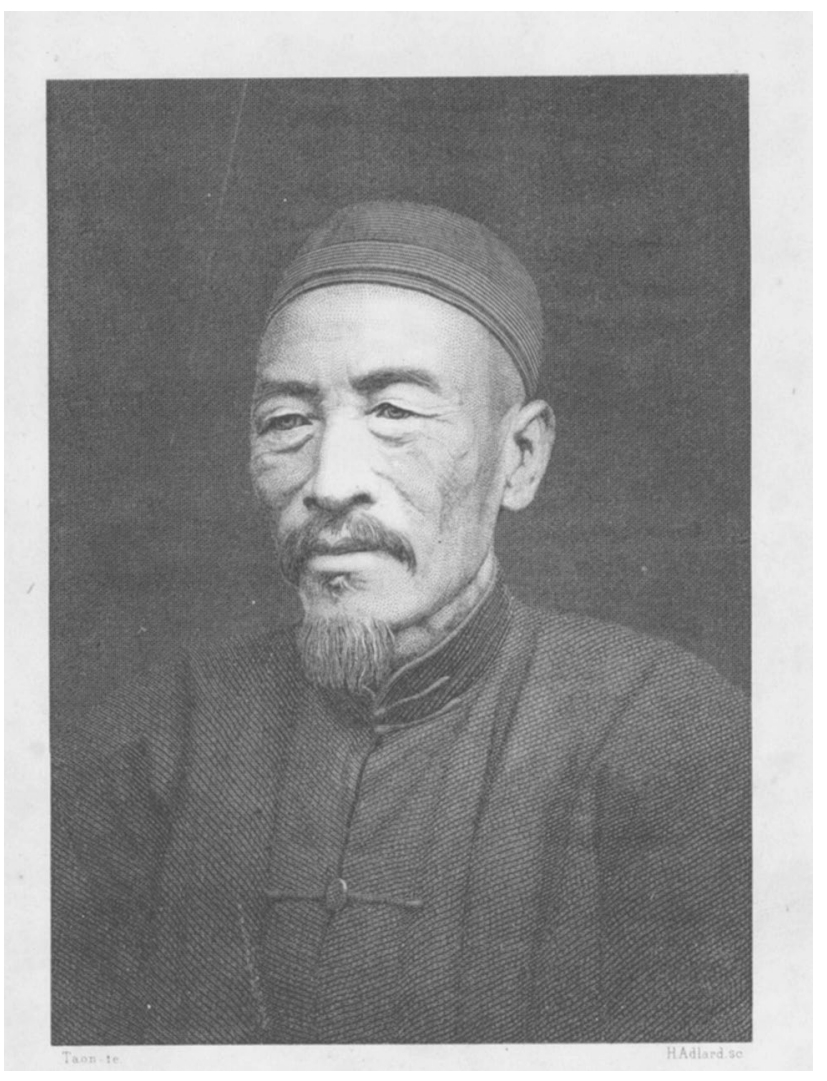

Fig. 6 Shou Xu

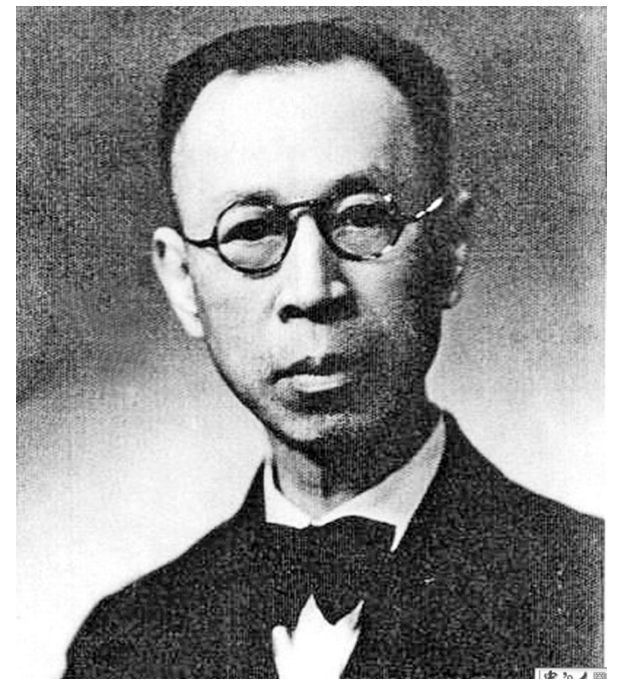

Fig. 7 Heqin Yu

The naming rules for Chinese binary inorganic names can be concluded with Zhenwen Zheng's words, "The anion name shall be in front and the cation name shall be behind. If both parts are anions or cations, we may place the more negative one in front. An element on the left or bottom part of the periodic table is more positive" [12]. The 1932 rules by the Ministry of Education for naming binary compounds and oxyacids were devised following a proposal by Zhengwen Zheng (鄭貞文, 1891-1969) (see Fig. 8), that reads, "a binary compound formed with one type of bonding is called X (an anion) hua Y (a cation)" [13]. Huaxue Mingming Yuanze (化學命名原則, The Principles of Chemical Nomenclature), issued in 1933, determined that inorganic binary compounds should have the word hua between the two elements, "a simple binary compound formed by just one kind of chemical bond shall be called X hua $\mathrm{Y}$ or $\mathrm{X}$ hua ya $\mathrm{Y}$ where $\mathrm{X}$ is the anion's name and $\mathrm{Y}$ is the cation's name and the anion is placed in front of the cation". The word " $y a$ " (亞) refers to the cation's reduced valence, and is no longer recommended usage [14]. The Revised Principles of Chemical Nomenclature, published in 1945, only slightly modified this wording [15].

In addition to binary compounds, Chinese inorganic oxyacid names were also influenced by the Japanese language. Before China's Self-Strengthening Movement (1861-1895), Chinese oxyacid names were mostly coined during the Late Ming period. The making of some oxyacids were introduced in the article "The Making of Strong Water" written by Guangqi $\mathrm{Xu}$. This book borrowed its contents from an alchemy book translated by the Jesuits. The word for acid in the original source was Latin "aqua fortis" where aqua means water and fortis means strengthened or fortified. The corresponding Chinese word used by that author was strong water (強水, qiangshui). However, aqua fortis refers to nitric acid, rather than any acid [16]. The Bowu Xinbian (博物新 編, New Treatise on Natural Philosophy and Natural History, 1855) reused this name and introduced the making of sulfuric acid (碏強水, huang qiangshui, brimstone strong water), nitric acid (㗂強水, xiao qiangshui, salpeter strong water) and hydrogen chloride (鹽強水, yan qiangshui, salt strong water) [17].

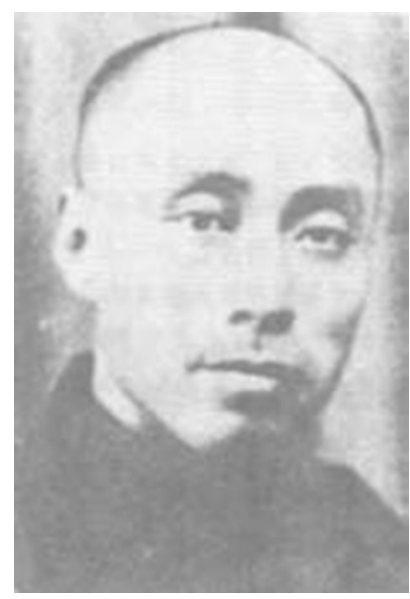

Fig. 8 Zhengwen Zheng 
Two acids, sulfuric acid (硫㣴酸, liuhuang suan) and nitric acid (淡酸, dan suan), have appeared in the periodical Liuhe Congtan (六合丵談, On the Universe), published by some missionaries, where the Chinese word "suan" (酸) for acid is still in use. In the book Gewu Rumen (格物入門, Introduction to Natural Philosophy) of 1868, even though its author William Alexander Parsons Martin introduced not too many inorganic acids, many common names are still used today, such as carbonic acid (炭/碳酸, tan suan, carbon acid), nitric acid (硝酸, xiao suan, salpeter acid), hydrogen chloride (鹽酸, yan suan, salt acid) and sulfuric acid (磺/硫 酸, huang suan, brimstone acid).

The two books Huaxue Chujie (化學初階, Basic Chemistry) and Huaxue Jianyuan (化學鑒原, Elementary Chemistry) used a different approach to form names based on their chemical formulae, such as chlorine oxygen7, chlorine oxygen5, chlorine oxygen 4 and chlorine oxygen [7]. On the other hand, Billequin had a completely different proposal for creating inorganic names. For example, he divided acids into five categories: very strong, strong, lesser strong, acid and lesser acid (jiqiang, 極強; qiang, 強; ciqiang, 次強; suan, 酸; cisuan, 次酸). As a result, chlorine-containing acids were named very strong chlorine, strong chlorine, lesser strong chlorine, chlorine acid and lesser chlorine acid (jilüqiang, 極綠強; lüqiang, 綠強; cilïqiang, 次綠強; lüsuan, 綠酸; cilüsuan, 次綠酸) [9].

Later, the inorganic names of the China Medical Missionary Association (博醫協會) and the Educational Association both adopted Billequin's methodology. The Educational Association believed that names based on chemical formulae failed to illustrate their chemical properties. As for inorganic acids, the Educational Association proposed to use shang (上, super-) xia (下, sub-), (強, greater-) and ruo (弱, lesser-) to describe an acid's strength, e.g. lüshangsuan (氯上酸, hyperchloric acid), lüqiangsuan (氯強酸, chloric acid), lüruosuan (氯弱酸, chlorous acid) and lüxiasuan (氯下酸, hypochlorous acid) [18].

At the turn of the 20th century, chemical books published by China's Christian churches such as Huaxue Xiangyao (化學詳要, A Detailed Examination of Chemistry) adopted the Educational Association's inorganic acid naming scheme [19]. However, many other chemical books adopted Japanese inorganic names, i.e. using a prefix to denote the strength of acidity, i.e. guo (過, per-, as in perchloric acid or $\mathrm{HClO}_{4}$ ), ya (亞, as in chlorous acid or $\mathrm{HClO}_{2}$ ) and ciya (次亞, hypo-, as in hypochlorous acid or $\mathrm{HClO}$ ) [20]. The title Huaxue Yuhui (化學語氣), adopted the element names of Huaxue Jianyuan. Additionally, the National Medical and Pharmaceutical Association of China (中華民國醫藥學會) also proposed to name inorganic oxyacids according to the number of oxygen atoms. They preferred the use of the prefixes guo, ya and ciya, first introduced by Japanese authors [21]. This method was adopted with an exception: the review board replaced the prefix ciya (次亞) with monosyllabic $c i$ (次) [22]. In the mean time, Zhenwen Zheng proposed a more detailed scheme, by using the prefixes guo (過), ya (亞), gao (高), di (低) and diya (低亞) to denote compounds having different numbers of oxygen atoms and oxidation values. Taking sulfur's oxyacids as an example, Zheng had created the names, ya ryuusan (亞硫酸, sulfurous acid, $\mathrm{H}_{2} \mathrm{SO}_{3}$ ), guo ryuusan (過硫酸, permonosulfuric acid, $\mathrm{H}_{2} \mathrm{SO}_{5}$ ), ci ryuusan (次硫 酸, sulfoxylic acid, $\mathrm{H}_{2} \mathrm{SO}_{2}$ ), gao ryuusan (高硫酸, persulfuric acid, $\mathrm{H}_{2} \mathrm{~S}_{2} \mathrm{O}_{8}$ ), di ryuusan (低硫酸, hyposulfuric acid, $\mathrm{H}_{2} \mathrm{~S}_{2} \mathrm{O}_{6}$ ) and diya ryuusan (低亞硫酸, hyposulfurous acid, $\mathrm{H}_{2} \mathrm{~S}_{2} \mathrm{O}_{4}$ ) [12].

The oxyacid names approved by the Ministry of Education were all the same as Zheng's version, i.e. with prefixes of guo, ya, gao, di and diya. The Principles of Chemical Nomenclature (化學命名原則) of 1933 was the publication of the above-mentioned result [14]. The Revised Principles of Chemical Nomenclature, published in 1945, did not come with any substantial changes. Only certain wordings and article numbers were revised [15].

\section{Japanese inorganic names}

In Seimi Kaisou (舍密開宗, Epitome of Chemistry, 1837), we witness an early attempt to create Japanese inorganic names. This book introduced inorganic binary compounds such as iou ka suisou (硫化水素, $\mathrm{H}_{2} \mathrm{~S}$ ), iou ka karuki (硫化 加爾基, CaS) and lin ka karuki (燐化加爾基, $\mathrm{Ca}_{3} \mathrm{P}_{2}$ ) [23]. At that point, many Japanese authors adopted this naming scheme and the order of elements was reversed compared to that of the formula [24].

Kagaku Yogoshu (化学要語集, カガク ヨウゴシュウ, $A$ Chemistry Lexicon) is a seven-page-long manuscript prepared by Udagawa Jun'ichi (宇田川潐一, 1848-1913) which named binary compounds in the format of $\mathrm{X} \mathrm{ka} \mathrm{Y}$ where the word $k a$ (化) means change, such as iou ka tetsu (硫化 鐵, $\mathrm{Fe}_{2} \mathrm{~S}_{3}$ ) or in the case of non-metal binary compounds, lin ka suisou (磷化水素, $\mathrm{PH}_{3}$ ) or iou ka suisou (硫化水素, $\mathrm{H}_{2} \mathrm{~S}$ ) [25]. Many later authors adopted this $\mathrm{X} k a$ Y naming scheme, including Ueno Hikoma's (上野彦馬, 1838-1904) Seimikyoku Hikkei (舎密局必携, A Must-Have Lab Manual, 1862), Takehara Heijiro's (竹原平次郎) Kagaku Nyuumon (化學入門, An Introduction to Chemistry, 1867-1870), Ichikawa Seizaburo's (市川盛三郎) Rika Nikki (理化日 記, Notes for the Physics and Chemistry Lectures, 1870), Udagawa, Jun'ichi's (宇田川準一) Kagaku Tekiyo (化学摘 要, An Abstract of Chemistry, 1870), Toki Yorinori's (土岐 頼徳) Kagaku Senyo (化学闡要, An Outline of Chemistry, 1872), Kashiwabara Gakuji's (柏原學而) Rosko Kagaku Shinsho (羅斯古化学新書, Roscoe's New Chemistry, 1877), Tamba Keizo's (丹波敬三) Muki Kagaku (無機化 
學, Inorganic Chemistry, 1878) and Ota Yunei’s (太田雄 寧) Shinshiki Kagaku (新式化學, New Chemistry, 1890).

The Kagaku Goi (化学語彙, A Vocabulary of Chemical Terms, 1900) did not mention binary compound naming. Such naming was introduced in its 1906 revision: the cation name is in front and the anion is placed behind. The cation's suffix suo (素, element), if it has one, is eliminated. Thus, for example, you have en(sou) $\mathrm{ka}$ gin [塩(素)化銀, $\mathrm{AgCl}$ ] and iou(sou) ka aen [硫(素)化亜鉛, $\mathrm{ZnS}$ ] [26]. This method is still in use.

The book Seimi Kaisou was among the earliest ones to give inorganic oxyacids kanji names. This book had introduced aryuusan (亞硫酸, sulfurous acid), ryuusan (硫酸, sulfuric acid), alinsan (亞磷酸, phosphorous acid) and linsan (磷酸, phosphoric acid) to Japanese readers [27]. Subsequently, prefixes such as ji- $a$ (次亞, じあ), $a$ (亞, あ), $j i$ (次, l゙) and $k a$ (過, 加) were introduced in the book Seimikyoku Hikkei (舎密局必携, A Must-Have Lab Manual, 1862), translated by Ueno Hikoma (上野彦馬, 1838-1904), such as 次亞格羅耳酸 $(\mathrm{ClO})$, 亞酸化格羅耳酸 $\left(\mathrm{ClO}_{3}\right)$, 次 酸化格羅耳酸 $\left(\mathrm{ClO}_{4}\right)$, 格羅耳酸 $\left(\mathrm{ClO}_{5}\right)$ and 過酸化格羅 耳酸 $\left(\mathrm{ClO}_{7}\right)$ [24]. The book Kagaku Kunmou (化學訓蒙, An Introduction to Chemistry) used similar names, including 次亞格魯兒酸 $(\mathrm{ClO})$, 亞格羅耳酸 $\left(\mathrm{ClO}_{3}\right)$, 次格魯兒 酸 $\left(\mathrm{ClO}_{4}\right)$, 格魯兒酸 $\left(\mathrm{ClO}_{5}\right)$ and 過格魯兒酸 $\left(\mathrm{ClO}_{7}\right)$ where the word sanka (酸化, さんか, oxidation) was eliminated. In another book, Kagaku Senyo (化学㘓要, An Outline of Chemistry), many Japanese names were accompanied by their European language names, including liusan (硫酸, sulfuric acid), aliusan (亞硫酸, sulfurous acid), jiliusan (次硫酸, hyposulfuric acid) and jialiusan (次亞硫酸, hyposulphurous acid) [28].

Several inorganic acids were introduced by the Kagaku Yakugoshu (化學譯語集, A Lexicon of Chemistry) which included sulfuric acid and sulfurous acid. However, this book did not discuss any principles or rules. Not until Kagaku Goi (化学語彙, A Vocabulary of Chemical Terms) of 1900 did they ever explain how these inorganic acids were named. They named the acids using their oxygen numbers and valences. They then named the most important and common variety of acid as the base acid of a series. They then compared other acids with this acid. An acid with one less oxygen than the base acid shall be called a ya acid while two less than the base acid shall be called a ciya acid. If the root of an acid in the series has a value the same as the base acid with one more oxygen, it will be called a guo acid. On the other hand, if both the value and oxygen number are one less than the base acid, it will be called a $c i$ acid. For example, a series with chlorine is listed here: 過塩素酸根 $\left(\mathrm{ClO}^{\prime}\right)$, 塩素酸根 $\left(\mathrm{ClO}^{\prime}\right)$, 亞塩素酸根 $\left(\mathrm{ClO}^{\prime}\right)$ and 次塩鹽素酸 根 $\left(\mathrm{ClO}^{\prime}\right)$ [29].

\section{Comparisons and exchanges}

Needless to say, after the First Sino-Japanese War, Chinese binary inorganic compound names were significantly influenced by Japanese, i.e. $\mathrm{X}$ hиa $\mathrm{Y}$ where $\mathrm{X}$ and $\mathrm{Y}$ are elements in reverse formula order and hua means "change". Even though this approach could be redundant because European languages do not need the word hua, this approach was widely adopted by many Chinese scholars, translators and academic institutions, and resulted in many books. Very few people were against this nomenclature. Therefore, this Japanese approach was adopted by Chinese people [30].

Additionally, Chinese oxyacid names were also affected by Japanese. However, even though Chinese names also used the four prefixes (ka/guo, a/ya, ji/ci, ji-a/ciya), their use in Chinese names were slightly different. Except for $a / y a$, the other three prefixes could be used on different inorganic acids.

In Japanese, kanji prefixes were limited to $k a, a, j i$ and $j i-a$. Many other inorganic names, such as permonosulfuric acid and sulphoxylic acid, were written in either katakana or hiragana, e.g. chio ryuusan (チ才硫酸, $\mathrm{H}_{2} \mathrm{~S}_{2} \mathrm{O}_{3}$ ), nichon ryuusan (二チ才ソ硫酸, $\mathrm{H}_{2} \mathrm{~S}_{2} \mathrm{O}_{6}$ ) [31] and karoshisan (力口 一氏酸, Caro's acid, $\mathrm{H}_{2} \mathrm{SO}_{5}$ ) [32]. They did not have unified names before 1945 . Today they are all written in katakana, such as ペルオワソ(一) 硫酸 and スルホキシル酸 [33]. The Japanese adoption of the four kanji prefixes was caused by their Chinese adoption as described by Billequin, and the Educational Association.

\section{Discussions and conclusions}

The First Sino-Japanese War completely changed the way China learned from the West. In 1898, Zhang Zhidong (1837-1909), one of the reformist representatives, published Quanxue pian(勸學篇, Advice on study) that was issued to the provinces to explain why Chinese people wanted to go to Japan to study Western science and technology. He believed that studying in the West was not as good as studying in the East. There were several advantages to studying in Japan: the distance was shorter, the cost was less, the language was closer, and the Japanese had already deleted those parts not suitable for Eastern countries [34]. This article thus encouraged a large number of Chinese students to study in Japan. In 1904, there were between 8000 and 10,000 Chinese students studying in Japan, and by 1906 at least 13,000 [35].

Both China and Japan had movements to learn Western science and technology in the 1870s. One of the biggest differences between the two was the establishment of a modern Western education system. Although the Manchu government established Tongwen College and hired Western 
teachers and experts, the education system of Tongwen College still stayed under the imperial examination system. In other words, although the students of Tongwen College studied Western science, they cared only about the imperial examination. In addition, under the recommendation of Rong Yi (1828-1912), the first Chinese to graduate from Yale University (1854), the Manchu government selected 120 young children (average age 12 years) to study in the United States in 1872-1875. The project was finally terminated because the behaviour of these students was considered to be inconsistent with the standards of Confucian ethics. The implementation of a national education in Qing China had to wait until 1904, and the imperial examination system was abolished in 1905 .

In other words, in the entire Westernisation Movement, the true decision-maker of how Chinese learned Western science was Confucianism. Just as Chinese senior officials debated at the time whether students of Tongwen College want to study Western science, regardless of positive and negative opinions, the basis of the arguments amounted to whether it was all in line with Confucian values. Although there had been several war failures with Western countries, the Chinese believed that Confucian spiritual culture was superior to Western Christianity. In this case, when Chinese students learned Western science, it (and they) must be based in Confucianism. In the wisdom of the Chinese, as long as the Western science books were translated, the belief was that the Chinese could learn Western science and would certainly surpass the Western countries in the future. Therefore, during the movement of Fuguo qiangbing (富國 强兵, rich nation, strong military), the Manchu government basically introduced only Western science and technology related to steam engines, mining, metallurgy, shipbuilding, railway and industrial development, and military technology.

Under the policy of rich nation, strong military, after the Meiji Restoration in Japan, foreign experts were hired, such as Scottish engineer Henry Dyer (1848-1918), British chemist Edward Divers (1837-1912) and English analytical and applied chemist Robert W. Atkinson (1850-1929). In addition, Japanese students were sent to study in Europe and the United States. For example, in 1871, 11 students were sent to study Western natural sciences, including Nagai Nagayoshi (長井長義, 1845-1929), Shibata Shōkei (柴田承 桂, 1850-1910), Kikuchi Dairoku (菊地大麓, 1855-1917), Yatabe Ryōkichi (矢田部良, 1851-1899) and others [36]. Higher education institutions were also established, such as the University of Tokyo, which was established in 1877. Moreover, compulsory national education was promulgated in 1879. It was implemented in accordance with the Western education system. This strategy and method of developing science was very different from that of China.

During the 19th century, Lavoisier's inorganic names appeared in books by Billequin and the Educational
Association. These inorganic names describe a compound's chemical properties such as its elements, whether it is an acid, base, or salt and also its strength. However, except for inorganic acids, most other 20th century inorganic names are not so descriptive.

Even though Japanese chemical names had such an impact in China, the adoption of element names was barely comparable to that of inorganic names. The nature of the terms was very probably the cause. Many Chinese terms are single-syllable words while Japanese terms can be multiplesyllable names transcribed from European languages into Japanese katakana. Most Chinese speakers could barely accept lengthy multisyllabic terms. So why did many Chinese people finally adopt single-syllable transcribed names? Neither descriptive nor phonic names were clearly understandable to early Chinese learners. However, with a little explanation, Chinese learners could understand and memorize descriptive names better. For those who had not been exposed to European languages, phonic names were totally incomprehensible. They had to at least learn English to understand what these strange words meant, which was very burdensome to them.

The question of why some terms can be used but others cannot, has always been one of the focuses of research on chemical terms. On this issue, David Wright uses Darwin's theory of evolution to describe the standardisation of Chinese chemical terms, but this theory is inconsistent with the facts [37]. If explained by evolutionary theory, these terms could not be used as today's chemical terms because they conform to the social environment at the time. For example, in the case of chemical element terms, according to Chinese society at the time, the social condition was that the Chinese did not know the 26 letters of the English alphabet, plus Western culture was almost unrecognisable to the Chinese. Therefore, literal or liberal translations were the preferred translation methods in 19th century China. But most of the Fryer element terms were synthesized by a syllable in the Western pronunciation and Chinese radicals [for example: argon (㲷, ya), iodine (碤, dian), barium (鋇, bei), calcium (鉦, gai), and magnesium (鎂, mei)]. Although it was only represented by one character, such a Western-style phonetic character was a great burden to the Chinese people in the late Qing period. This social environment was very different from today's environment. In the 19th century, the Chinese asked why they should learn English. In today's society, they ask why they should not learn English. In the 19th century, the Chinese did not understand why Fryer created such strange phonetic characters that were almost impossible to use. However, the Chinese in the 21st century will admire Fryer's wisdom in creating such terms that conformed to the trend of the times. The element terms translated by Billequin in Tongwen College were the most suitable for the needs of the society at that time, because most of his elemental terms 
were either literal or liberal translations. And this is also why the Yizhi Shuhui (盆智書會, School and Textbook Series Committee) proposed more literal and liberal translations of element terms in order to conform to the social environment of the time [38]. Therefore, in the list of elements they had unified, only a few of Fryer's terms were adopted. But in the end, it was Fryer's phonetic characters that were used, although their terms were not suitable for Chinese society in the 19th century.

As far as inorganic terms were concerned, it was also not suitable to explain the terms by evolutionary theory, because Japanese inorganic terms almost directly replace Chinese inorganic terms. The reason why Fryer's element terms and Japanese inorganic terms can be used was not because they can adapt to the social environment at that time but, most importantly, because they can provide a larger amount of chemical knowledge, which was impossible for other terms. Fryer translated far more chemistry books than any other person, and eventually formed a knowledge system. For example, the element terms of Fryer were used in the books Huaxue Jianyuan (化學鑑原, Elemental Chemistry), Huaxue Jianyuan Xubian (化學鑑原續編, A Sequel to Elemental Chemistry), Huaxue Jianyuan Bubian (化學 鑑原補編, A Supplement to Elemental Chemistry), Huaxue Xuzhi (化學須知, Elementary Chemistry), Huaxue Yizhi (化 學易知, Chemistry Outlines) and Gezhi Huibian(格致彙編, The Chinese Scientific and Industrial Magazine. Billequin relied only on the Huaxue Zhinan (化學指南, A Guide to Chemistry) and Huaxue Chanyuan (化學闡原, Advances in Chemistry) to spread knowledge. The chemical terms of the School and Textbook Series Committee appeared only at the end of the 19th century. The release of chemical books was not able to have much effect at the beginning of the 20th century. As for the publication of Japanese chemistry books in the early 20th century, a large number of Japanese chemical element terms were used, which did not replace Fryer's element terms that had formed the power of knowledge, but quickly replaced his inorganic terms. The reason was that the Manchu inorganic chemistry knowledge system was weak or had not yet formed an inorganic knowledge system, and thus it was replaced by Japanese inorganic terms that provide a large amount of inorganic knowledge.

When a new systemic term appeared, its purpose was to provide new knowledge. When there was no stable government, there was no lasting education system, and there was no unified textbook. The more the systematic terms could provide knowledge, the more opportunities they had to be adopted. In other words, the ability to provide a richer and more systematic knowledge was the most critical factor in determining whether a term was adopted.

\section{References}

1. Wang YZ (1991) Qingmo yizhi shuhui tongyi keji shuyu gongzuo shuping [A summarization and review on the work of standardizing scientific Terminology by EAC in the late Qing]. Chin J Hist Sci Technol 12:9-19

2. Reardon-Anderson J (1991) The study of change: chemistry in China, 1840-1949. Cambridge University Press, Cambridge

3. Chang H (2018) What's in a name: a comparison of Chinese and Japanese approaches to the translation of chemical elements. ChemTexts 4:1-12

4. De Morveau LG (1788) Method of chymical nomenclature. G. Kearsley, London

5. Hobson B (1858) A medical vocabulary in English and Chinese. Shanghai Mission Press, Shanghai

6. Martin WAP (1868) Gewu rumen [Introduction to natural philosophy]. Tongwen College, Beijing

7. Kerr JG, He LR (1870) Huaxue chujie [First steps in chemistry]. Boji Hospital, Canton

8. Fryer J, Xu S (1871) Huaxue jianyuan [Elementary chemistry]. Jiangnan Arsenal, Shanghai

9. Billequin A, Lian ZZ (1873) Huaxue zhinan [Guide to chemistry]. Tongwen College, Beijing

10. Yu HQ (1903) Xueming luejie- shi huaxue ming [A brief explanation of the scientific name: chemical terms]. Kexue shijie [Scientific world] 5:95-102

11. Yu HQ (1903) Huaxue ding mingbiao[Chemical name list]. Kexue shijie [Sci World] 2:91-96

12. Zheng ZW (1920) Wuji huaxue mingming caoan [Inorganic chemical naming draft]. The Commercial Press, Shanghai

13. National Institute for Compilation and Translation (1932) Jiaoyu bu huaxue taolun hui zhuankan [Monograph for Ministry of Education chemistry seminar]. National Institute for Compilation and Translation, Nanjing

14. National Institute for Compilation and Translation (1933) Huaxue mingming yuanze [Principles of chemical nomenclature]. Zhengzhong Press, Nanjing

15. National Institute for Compilation and Translation (1945) Zengding huaxue mingming yuanze [The revised principles of chemical nomenclature]. Zhengzhong Press, Nanjing

16. Yuan HQ (1956) Zhongguo huaxue shilun wenji [Proceedings of Chinese chemistry history]. Sanlian Press, Beijing

17. Hobson B (1855) Bowu xinbian [New treatise on natural philosophy and natural history]. Mohai Shuguan, Shanghai

18. Mateer CW (1901) Chemical terms and nomenclature. American Presbyterian Mission Press, Shanghai

19. Luff A, Page F (1905) Huaxue xiangyao [A manual of chemistry theoretical and practical, inorganic and organic]. Gillison T, Zhao QZ trans. The American Presbyterian Mission Press, Shanghai

20. Yu HQ (1913) Zhongxue huaxue jiaokeshu [Middle school chemistry textbook]. Wenming Press, Shanghai

21. The Chinese Pharmaceutical Association (1918) Huaxue mingci caoan [Draft chemical terms]. Jinghua Publishing House, Beijing

22. General Committee on Scientific Terminology (1920) Huaxue mingci [Chemical terms]. General Committee on Scientific Terminology, Shanghai

23. Takehara H (1867-1870) Kagaku nyuumon [An introduction to chemistry]. Ikkando, Tokyo

24. Hikoma U (1862) Seimikyoku hikkei [A must-have lab manual]. Iseya Jihei, Seishou

25. Miller WA (1867) Elements of chemistry: theoretical and practical. Wiley, New York

26. Takamatsu T, Sakurai J (1906) Kagaku Goi [A vocabulary of chemical terms]. Uchida Rokakuho, Tokyo 
27. Udagawa Y (1837) Seimi kaisou [Epitome of chemistry]. Seireikaku, Edo

28. Wells DA (1872) Kagaku senyo [An outline of chemistry]. Suzuki Kiuemon, Tokyo

29. Takamatsu T, Sakurai J (1900) Kagaku Goi [A vocabulary of chemical terms]. Uchida Rokakuho, Tokyo

30. Chang H (2006) Zhongwen wuji mingci zhi "hua" zi [The character hua (change) in Chinese inorganic nomenclature: 1896-1945]. Stud Hist Nat Sci 25:205-214

31. Ishikawa Y (1936) Shogai mukikagaku [inorganic chemistry fully explained]. Uchida Rokakuho, Tokyo

32. Shoji O (1942) Shinben Mukikagaku [A new inorganic chemistry]. Sankosha Co., Ltd., Tokyo

33. Isao O (1969) Kanmei kagaku meimeihou [Concise chemical nomenclature]. Ohmsha Books, Kyoto

34. Zhang ZD (1901) China's only hope. Oliphant, Anderson \& Ferrier, Edinburgh and London
35. Keishuu S (2012) Zhongguo ren liuxue riben shi [The history of Chinese students in Japan]. Peking University Press, Beijing

36. Imoto J (1978) 100 Nian riben huaxueshi [History of a hundred years of Japanese chemistry]. Kagaku-Dojin Publishing Company, Kyoto

37. Wright $\mathrm{D}$ (2000) Translating science: the transmission of Western chemistry into late imperial China, 1840-1900. Brill Academic Pub, Leiden

38. Mateer CW (1898) The revised list of the chemical elements. Chin Rec Mission J 29:87-94

Publisher's Note Springer Nature remains neutral with regard to jurisdictional claims in published maps and institutional affiliations. 